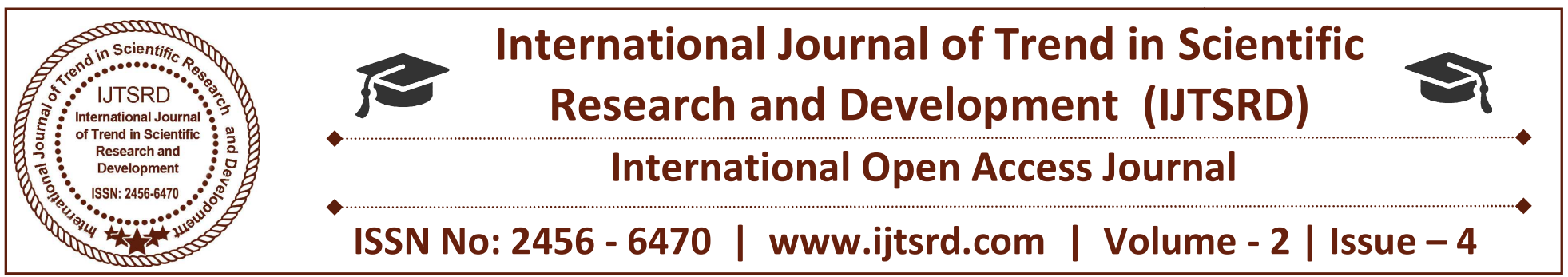

\title{
Relationship Between Teachers Motivation and Students Academic Performance
}

\author{
Ms. J. Josely ${ }^{1}$, Mrs. Vandana Devi ${ }^{2}$ \\ ${ }^{1}$ M. Ed Student, ${ }^{2}$ Assistant Professor in Pedagogy \\ RVS College of Education, Coimbatore, Tamil Nadu, India
}

\begin{abstract}
This paper examined the impact of teacher motivation on academic performance of students. It proceeded by defining teacher motivation as a general term applying to the entire class of drives, desires, needs, wishes and similar forces initiated for teachers, in order to induce them to act in desireable academically productive manner. On the other hands, it considered academic performance as the outcome of education; it constitute the extent to which a student, teacher or institution has achieved their educational goals. Determinants of teacher-learner interactions for better students academic performance were found to include -the status of teachers, class size, increasing workload, professional freedom, the work environment, teacher education and professional development, teachers' salaries and negotiations and consultations. Impacts of teacher motivation on the academic performance of students include among others-teacher motivation provides the de- sire in students to learn. This is because learners are encouraged to learn, to express themselves through answering questions, taking parts in both individual and group assignments; infact get involved or committed in the learning process by acquiring ideas, skills and concepts for total development. Finally, it was recommended among others that teacher should be paid salaries comparable with other professions requiring a similar level of qualifications and responsibility, making it possible for them to live with dignity on the salary from their work and not be forced to take on additional jobs
\end{abstract}

\section{INTRODUCTION}

No other profession has been subjected to so much scrutiny, debate and discussion as the teaching profession since educational quality both in developed

countries and developing countries has become a topic of intense interest, primarily because of countries efforts to maintain quality in the context of quantitative expansion of educational provision. Many countries have simultaneously implemented innovations based on more active approaches to teaching and learning further challenging education systems and, especially, teachers since with expansion and reform taking place at the same time, a severe burden has fallen on teachers to be flexible and to reject traditional approaches and to internalize and practice new approaches often within the context of conceptual confusion about the reforms and minimal understanding of them. Having once been the crucible of social optimism, education now became a target for purging, despair and panic Change became ubiquitous and was implemented with an escalating sense of urgency. And teachers were blamed for everything by everybody The result was extensive pressure on teachers. Burnout, morale problems and stress levels all increased. Many teachers started to feel professionalized as the effects of reform and restructuring began to bite. Teachers experienced more work, more regulation of their work, and more distractions from what they regarded as being the core to their work (teaching children) by the bureaucratic and form-filling burdens of administrative decentralization. As a result none of the innovations have an effect on fundamental school reform due to top-down orientation which have removed the persons responsible for implementation of the innovations from the initial decision making process.

Committed though he may be to the nurture of cognitive development, the encouragement of 
motivate-realization, or the promotion of citizen- ship, for example, he cannot help being affected by the doubts and uncertainties below the familiar surfaces of classroom and school. On the one hand, more is being asked of education than ever before in history; on the other hand, institutional education is being attacked for its inefficacy and is losing both legitimacy and support.

Held accountable for failures in his classes, asked to come forth with a better product to individualize, to become more immediately concerned, the teachers suddenly finds him motivate pulled in many directions. To whom is he responsible the community, the administrators of the schools, his students, and his profession? And for what is he responsible for? ...Teachers react in variety of ways. At times they screen out the scapegoating and incessant challenges to what they are doing. They bite down hard and say, It is better not to think about it. They concentrate on the daily routines, trying to be cool and disengaged, as functional and impersonal as machines. At other time the gap between what is asked for and what seems possible becomes so wide that they experience outrage or despair. They may then project their frustrations outward to the children or to the young people in their classrooms by inventing motivate fulfilling prophecies and resigning themselves to the likelihood that they and their students will fail. Most commonly, they behave like clerks, subjects of more remote authority that issues orders, supervises, and asks little more than conformity to custom, to the prevailing law. They are powerless and they accede. The importance of teacher motivation and empowerment in $21 \mathrm{st}$ century the informational society emerging from the ashes of old industrialism; considered education as the quality of labour and teachers as the new producers of informational capitalism- in key education areas cannot be underestimated. A belief by teachers that their knowledge of teaching and learning matters and is considered a valuable factor in decision-making can motivate them to connect to their schools in powerful ways. This connection can help improve the retention of those teachers in their classrooms and, ultimately, the success of the students they teach. As noted Who Controls Teachers Work? Power and Account- ability in Americas Schools,: Those who are en- trusted with the training of this next generation are not entrusted with much control over many of the key decisions in their work. He further pointed out that, The result of this disenfranchising of teachers will be schools that professionalize and demotivate teachers. This view indicating that the only way education will improve is if an invitation is issued for ideas from the people who work in the schools. These people are influential in determining which reforms are acceptable. Indeed, only those reforms that are found acceptable will be the ones that will have a positive effect on the school. Thus, when teachers are involved in making decisions about changes that affect them, enjoy being around children, have the skills to impart appropriate knowledge and manage their classrooms, and understand their role in the community, they are usually highly motivated and their students achievement tends to improve.

\section{REVIEW OF LITERATURE}

Ninkovi, S. R., \& Kneevi Flori, O.. (2018) acknowledged the role of collaborative relation- ships of teachers in improving the quality of instruction; teacher collective efficacy continues to be a neglected construct in educational research. The purpose of this paper is to explore the relations between transformational school leadership, teacher motivateefficacy and perceived collective teacher efficacy, using a sample of 120 permanent secondary-school teachers in Serbia, whose average age was 42.5. The results of the hierarchical regression analysis showed that transformational school leadership and teacher motivate-efficacy were independent predictors of teacher collective efficacy. The research findings also showed that individually-focused trans- formational leadership contributed significantly to an explanation of collective efficiency after controlling specific predictor effects of group focused dimensions of transformational leader-ship. It is argued that the results have a double meaning. First, this study expanded the understanding of the relationship between different dimensions of transformational school leadership and collective teacher efficacy. Second, a contribution of teacher motivate-efficacy to collective efficacy beliefs was established, confirming the assumptions of social cognitive theory on reciprocal causality between two types of perceived efficacy: individual and collective. Schiefele, U. (2017) addressed the role of elementary school teachers classroom management and mastery oriented instructional practices as mediators of the effects of teacher motivation on student motivation. The sample comprised 110 teacher class pairs (1731 students). The results from multilevel regression analyses revealed that teacher ed- ucational interest contributed to student reports of teachers instructional practices. 
These practices, in turn, were significant predictors of students subject interest and mastery goals at both the student and the class level. Barbieri, G., Rossetti, C., \& Sestito, P. (2017) likely to be a relevant factor affecting students learning. We exploit the fact that motivated teachers are typically those who have chosen to be in a given school, while teachers just waiting to move to another school may be rather demotivated. We link this dimension of teacher motivation as measured by the share of teachers who asked to leave their current school to students learning as measured by their scores in reading and math standardized tests in a national examination. Han, J., \& Yin, H. (2016) witnessed an increase in research on teacher motivation which has been proved a crucial factor closely related to a number of variables in education such as student motivation, educational reform, teaching practice and teachers psychological fulfilment and well-being. To address the constant calls for teacher motivation research, this paper attempts to pose a comprehensive review of teacher motivation studies conducted from diversified theoretical perspectives. Five research areas related to teacher motivation research have been identified: influencing factors of teacher motivation; teacher motivation and teaching effectiveness; teacher motivation and student motivation; teacher motivation research across different disciplines; and the instruments for assessing teacher motivation. Based on a critique of existing literature in terms of theoretical perspectives, research methodology, research content and concerns about contextual issues, potential directions for future research are finally proposed. Ryan, A. M., Kuusinen, C. M., \& BedoyaSkoog, A. (2015) examined the nature of teachers motivate-efficacy, differences between elementary and middle school teachers motivateefficacy and the implications for observed classroom quality. Teachers $(\mathrm{N}=101 ; 61 \mathrm{M} . \mathrm{Ed}$ and 85 different classes. The sample included 6th grade $(n=44)$ and 7 th grade $(n=30)$ teachers from six middle schools and 5 th grade teachers $(n=27)$ from twelve feeder elementary schools. Exploratory factor analysis indicated that teachers motivate- efficacy for managing peer relations is a distinct dimension from teachers motivate-efficacy for classroom management, instruction and student engagement. Teachers felt less efficacious about managing peer relations compared to classroom management and instruction. Further, middle school teachers reported lower motivate-efficacy for classroom management and managing peer relations compared to elementary school teachers. For elementary and middle school teachers, their motivate-efficacy for classroom management and for managing peer relations was associated with some aspects of observed classroom quality.

Butler, R. (2012) designed to extend Butlers (2007) model and measure of achievement goals for teaching, to recognize that teaching is an interpersonal endeavour, not just personal endeavour. In Study 1, results from 530 teachers in Israel confirmed the predicted 5-factor model comprising relational goals, whereby teachers aspire to create close and caring relationships with students, in addition to the previously identified mastery, ability-approach, ability avoidance, and work avoidance goals for teaching. Results from a subsample of 272 teachers confirmed that the teachers goals were coherently and differentially related to their teaching practices, assessed several months later. The most impor tant results showed that only relational goals predicted teacher social support; they also predicted mastery instruction. Teacher ability-approach and ability voidance goals both predicted performance instructional practices. Multilevel analyses of data from 73 teacher class pairs (1,790 students) in Study 2 showed that teacher relational goals also predicted student reports of teacher social support and mastery instruction; mastery goals were negatively associated with student perceptions of performance practices. Teachers goals, but not teachers reports of instruction, predicted students perceptions of instruction. The results supported extension of Butlers model to incorporate relational goals for teaching and confirmed that strivings to connect are at the heart of effective teaching. The results also shed new light on relations between teachers goals and teachers approaches to instruction and on teacher and student perspectives on instruction. Differences in boys and girls perceptions of instruction imply that it is important to consider possible Teacher standard differences in research on classroom goal structures. Goel, D. R., \& Goel, C. (2016) intent of the present paper is to enhance the teacher education quality in India by focusing on the emerging issues \& related concerns. Various issues of teacher education namely, institutional inertia, brand inequity, quality crisis, over growing establishment, rare humane and professional teachers, poor integration of skills, alienated and incompatible modes of teacher education, little contribution to higher education, domain pedagogy mismatches, identity crisis, rare innovations, stake 
holders non-alignment, inadequate technology infusion, little choice base, poor research scenario, vision and vision mismatches, non-scientific manpower planning, illusive laboratories, over activism of distance/open universities, invalid recognition and accreditation and no teacher education policy have been dwelt on in this paper. The paper concludes that teacher education system in India calls for revolutionary changes. Singh, R., \& Sarkar, S. (2015)) investigated how teaching quality impacts students outcomes in public and low fee charging private schools in India. Drawing on Young Lives longitudinal study, students in private schools have a significantly higher mathematics score than public schools. Across public and private schools, teachers characteristics such as experience, Teacher standard, content knowledge and general education qualifications do not have significant influence on students learning outcome. Proximity of teachers residence to the school, teachers professional qualification and teachers attitude towards schools and students and teaching practices such as regular checking of books, emerge as important determinants of students out- comes.

Batra, P. (2014) examined the intimate relationship between pedagogic practices and the education of teachers within the larger contemporary Indian context. The first part of the paper examines this relationship in the light of a neo- liberal economic and social engineering-oriented policy discourse which is centred on concerns of national competitiveness in a globalising world. This has gained momentum in India over the last decade with the increasing engagement of the corporate sector in education, leading to a superficial policy consensus. In practice, the tension between policy imperatives and the lived reality of school education continues. This is further accentuated by an entrenched teacher education discourse and practice that has wrapped it motivate in dualities, is circumscribed and resistant to meaningful interrogation and challenge. It is argued that classroom pedagogy is being shaped by the culture and social ethos of teacher education as much as the neo-liberal frame within which teachers work and worth is being viewed and judged. The paper brings to light the tenuous epistemological frame that currently structures the experiences of those preparing to be teachers. It argues for the need to engage with more robust epistemological underpinnings in designing teacher education programmes. Yuan, K., Le, V. N., McCaffrey, D. F., Marsh, J. A., Hamilton,
L. S., Stecher, B. M., \& Springer, M. G. (2013) drew on teacher survey responses from randomized experiments exploring three different pay-forperformance programs to examine the extent to which these programs motivated teachers to improve student achievement and the impact of such programs on teachers instruction, number of hours worked, job stress, and collegiality. Results showed that most teachers did not report their program as motivating. Moreover, the survey responses suggest that none of the three programs changed teachers instruction, increased their number of hours worked or job stress, or damaged their collegiality. Future research needs to further examine the logic model of pay-forperformance programs and test alternative incentive models such as rewarding teachers based on their practices and job responsibilities rather than on student outcomes.

\section{OBJECTIVES OF THE STUDY}

1. To study the relationship between teachers motivation and students academic performance.

2. To develop a questionnaire to assess the relationship between teachers motivation and students academic performance.

3. To find out the relationship between teachers motivation and students academic performance.

4. To find out the relationship between teachers motivation and students academic performance with respect to Teacher standard.

5. To find out the relationship between teachers motivation and students academic performance with respect to school type.

6. To find out the relationship between teachers motivation and students academic performance with respect to parent education.

7. To find out the relationship between teachers motivation and students academic performance with respect to parent occupation.

\section{RESEARCH QUESTIONS}

1. Is there any significance mean score difference between teachers motivation and students academic performance and Teacher standard?

2. Is there any significance mean score difference between teachers motivation and students academic performance and school type?

3. Is there any significance mean score difference between teachers motivation and students academic performance and parent education?

4. Is there any significance mean score difference between teachers motivation and students academic 
performance and parent occupation?

\section{HYPOTHESES}

1. There will be a significant mean score difference between teachers motivation and students academic performance and Teacher standard.

2. There will be a significant mean score difference between teachers motivation and students academic performance and school type.

3. There will be a significant mean score difference between teachers motivation and students academic performance and parent education.

4. There will be a significant mean score difference between teachers motivation and students academic performance and parent occupation.

\section{VARIABLES}

An independent variable is a variable that is expected to influence the dependent variables. Its value may be changed or altered, which is independent of any other variables. Also the following demographic variables were used as independent yariables.

$>$ Teacher standard (B.Ed/M.Ed).

$>$ School Type (Government/Private).

$>$ Parent Education (Educated/Uneducated).

$>$ Parent Occupation (Government/Private).

Dependent variableare those events which are by hypothesized as dependent on the changes in the dependent variable (Relationship between teachers motivation and students academic per formance.).

\section{DESIGN OF THE STUDY}

In the presence study Normative survey method will be adopted. Survey research employee questioner and interview to our people who provide informations about them selfs their attitude and believes demographic (Age, Teacher Standard Income and So on) the survey method can be classified into many, but according to the objectives and hypotheses in this presence study normative survey method will be adopted.

\section{POPULATION AND SAMPLE}

Coimbatore district is one of the district in Tamilnadu, India. Coimbatore is finest education district of Tamilnadu. It is the second largest city in Tamilnadu and one of the fastest growing cities in Tamilnadu State. For the present study the investigator select only 6 Schools from both Government and Private School around Coimbatore. Investigator selected
Datas will be collected from the samples of 282 Students of various schools.

\section{SAMPLING TECHNIQUES}

Sampling procedure is a definite plan determined before any data are actually collected for obtaining a sample from a given population under the simple random sampling technique. This sampling method is used for selecting samples. Simple random sampling is method in which each and every element in the population has an equal chance of getting selected. The study is based on primary data which is collected from 282 school students at higher secondary level and around Coimbatore district. The sample which was collected from various college located in and around Coimbatore is shown as below.

Table 1.1 List of schools used for data collection

\begin{tabular}{|l|l|l|}
\hline S. & \multicolumn{1}{|c|}{ Name of the schools } & $\begin{array}{c}\text { Number } \\
\text { of } \\
\text { students }\end{array}$ \\
\hline 1. & $\begin{array}{l}\text { Kennedy Matriculation Higher } \\
\text { Secondary School, Sulur }\end{array}$ & 44 \\
\hline 2. & $\begin{array}{l}\text { Sri Ramaswamy Naidu } \\
\text { Vidyalayam Higher Secondary } \\
\text { School, Sulur }\end{array}$ & 42 \\
\hline 3. & $\begin{array}{l}\text { Michael Job Matriculation } \\
\text { Higher Secondary School, } \\
\text { Sulur, }\end{array}$ & 44 \\
\hline 4.6 & $\begin{array}{l}\text { Government Boys Higher } \\
\text { secondary School, Sulur }\end{array}$ & 52 \\
\hline 5. & $\begin{array}{l}\text { Government Girls Higher } \\
\text { secondary School, Sulur }\end{array}$ & 58 \\
\hline 6. & $\begin{array}{l}\text { Government Higher Secondary } \\
\text { School Irugur }\end{array}$ & 42 \\
\hline
\end{tabular}

TABLE 1.2

Distribution of samples based on variables

\begin{tabular}{|l|l|l|l|l|}
\hline Category & Subgroups & Number & $\%$ & Total \\
& & & & \\
\hline $\begin{array}{l}\text { Teacher } \\
\text { Standard }\end{array}$ & B.Ed & 184 & 65 & 282 \\
\cline { 2 - 5 } School Type & M.Ed & 98 & 35 & \\
\cline { 2 - 5 } & Government & 152 & 54 & 282 \\
& Private & 130 & 46 & \\
\hline $\begin{array}{l}\text { Parent } \\
\text { Education }\end{array}$ & Educated & 172 & 61 & 282 \\
\cline { 2 - 5 } & Uneducated & 110 & 39 & \\
\hline $\begin{array}{l}\text { Parent } \\
\text { Occupation }\end{array}$ & Government & 94 & 33 & 282 \\
\cline { 2 - 5 } & Private & 188 & 67 & \\
\hline
\end{tabular}




\section{RESEARCH TOOL}

Tool become another major consideration in an education research. The instrument employed for the collection of data required for the study of any problem is called tool. Tool employ distinction way of describing and qualifying the data the important tools of educational research include interview schedule, questionnaire, observation, rating scale, proficiency test, psychological tests and sociogram.

\section{TESTING HYPOTHESIS 1:}

There will be a significant mean score dif- ference between teachers motivation and students academic performance and Teacher standard.(B.Ed/M.Ed).

\section{TABLE 1.3}

Mean Score difference and t- value of factors related to level of study on teachers motivation and students academic performance and Teacher standard

\begin{tabular}{|l|l|l|l|l|l|l|}
\hline $\begin{array}{l}\text { S. } \\
\mathbf{N} \\
\mathbf{0}\end{array}$ & $\begin{array}{l}\text { Teacher } \\
\text { Stan- } \\
\text { dard }\end{array}$ & $\mathbf{N}$ & Mean & Df & $\begin{array}{l}\text { t- } \\
\text { Value }\end{array}$ & $\begin{array}{l}\text { Re- } \\
\text { sult }\end{array}$ \\
\hline 1 & B.Ed & 184 & 1.5856 & & & \\
\cline { 1 - 5 } 2 & M.Ed & 98 & 1.4129 & 281 & 2.051 & S tid \\
\hline \multicolumn{2}{|l|}{ Total } & 282 & 1.4493 & & & \\
\hline
\end{tabular}

The Table 1.3 shows the mean score difference in level of study on teachers motivation and students academic performance based on Teacher standard (B.Ed/M.Ed). The calculate t value is statistically a significance at 0.05 levels and hence the hypotheses 1 is accepted. It can be concluded that there is a significant difference in mean score difference in level of study on teachers motivation and students academic performance based on Teacher standard.

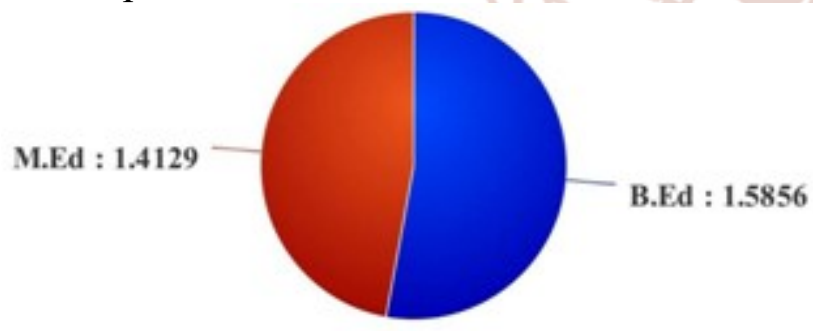

Figure 1: Relationship between Trainees Teacher Standard and Level of Study on Teachers Motivation and Students Academic Performance

\section{TESTING HYPOTHESIS 2:}

There will be a significant mean score difference in level of study on teachers motivation and students academic performance based on School Type(Government/Private).
TABLE 1.4

Mean Score difference and t- value of factors related to level of study on teachers motivation and students academic performance based on School Type(Government/Private).

\begin{tabular}{|l|c|c|c|c|c|c|}
\hline $\begin{array}{c}\text { S. } \\
\text { No }\end{array}$ & $\begin{array}{c}\text { School } \\
\text { type }\end{array}$ & $\mathbf{N}$ & Mean & Df & $\begin{array}{c}\text { t- } \\
\text { Value }\end{array}$ & $\begin{array}{c}\text { Re- } \\
\text { sult }\end{array}$ \\
\cline { 1 - 4 } 1 & $\begin{array}{l}\text { Govern } \\
\text { ment }\end{array}$ & 152 & 1.1752 & \multirow{2}{*}{281} & -2.631 & $\mathrm{~S}$ \\
\cline { 1 - 5 } 2 & Private & 130 & 1.3562 & & \\
\hline \multicolumn{2}{|l|}{ Total } & 282 & 1.2657 & & \\
\hline
\end{tabular}

The Table 1.4 shows the mean score difference in level of study on teachers motivation and students academic performance based on School Type(Government/Private). The calculate $t$ value is statistically a significance at 0.05 levels and hence the hypotheses 2 is accepted. It can be concluded that there is a significant difference in mean score difference in level of study on teachers motivation and students academic performance based on School Type.

Private : 1.3562

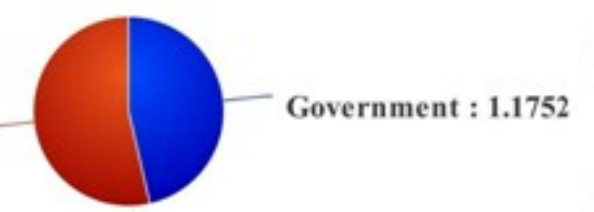

Figure 2: Relationship between Trainees School Type and Level of Study on Teachers Motivation and Students Academic Performance

\section{TESTING HYPOTHESIS 3:}

There will be a significant mean score difference in level of study on teachers motivation and students academic performance based on parents education (Educated/Uneducated).

\section{TABLE 1.5}

Mean Score difference and t- value of factors related to level of study on teachers motivation and students academic performance based on parents education (Educated/Uneducated).

\begin{tabular}{|l|l|l|l|l|l|l|}
\hline $\begin{array}{c}\text { S. } \\
\text { No }\end{array}$ & $\begin{array}{c}\text { Parents } \\
\text { Educa- tion }\end{array}$ & N & Mean & Df & $\begin{array}{c}\text { t- } \\
\text { Value }\end{array}$ & $\begin{array}{c}\text { Re- } \\
\text { sult }\end{array}$ \\
\hline 1 & Educated & 172 & 1.2832 & & & \\
\hline 2 & Uneducated & 110 & 1.732 & 281 & 0.908 & NS \\
\hline \multicolumn{2}{|l|}{ Total } & 282 & 1.2822 & & & \\
\hline
\end{tabular}

The Table 1.5 shows the mean score difference in level of study on teachers motivation and students academic performance based on parents education (Educated/Uneducated). The calculate $\mathrm{t}$ value is 
statistically no significance at 0.05 levels and hence the hypotheses 3 is rejected. It can be concluded that there is no significant difference in mean score difference in level of study on teachers motivation and students academic performance based on parents education (Educated/Uneducated).

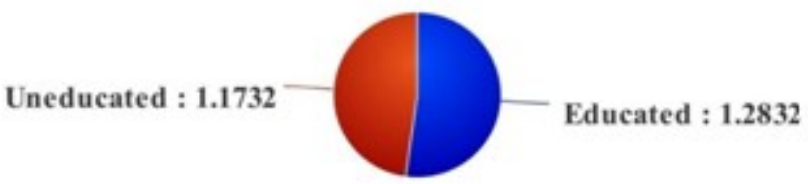

Figure 3: Relationship between Parents Education and Level of Study on Teachers Motivation and Students Academic Performance

\section{FINDINGS OF THE STUDY}

$>$ There is a significant relationship between teacher standard and level of study on teachers motivation and students academic performance.

> There is a significant relationship between School Type related factors and level of study on teachers motivation and students academic performance.

$>$ There is no significant relationship between parents education related factors and level of study on teachers motivation and students academic performance.

$>$ There is a significant relationship between Parent Occupation and level of study on teachers motivation and students academic performance.

\section{TESTING HYPOTHESIS 4:}

There will be a significant mean score difference in level of study on teachers motivation and students academic performance based on Parent Occupation (Government/Private).

\section{TABLE 1.6}

Mean Score difference and $t$ - value of factors related to level of study on teachers motivation and students academic performance based on Parent Occupation (Government/Private).

\begin{tabular}{|l|c|c|c|c|c|c|}
\hline $\begin{array}{c}\text { S. } \\
\text { No }\end{array}$ & $\begin{array}{c}\text { Parent } \\
\text { Occupation }\end{array}$ & N & Mean & Df & $\begin{array}{c}\text { t- } \\
\text { Value }\end{array}$ & $\begin{array}{c}\text { Re- } \\
\text { sult }\end{array}$ \\
\hline 1 & Government & 94 & 1.0891 & & & \\
\cline { 1 - 5 } 2 & Private & 188 & 1.4121 & 281 & -2.325 & NS \\
\cline { 1 - 5 } & 282 & 1.2506 & & & \\
\hline
\end{tabular}

The Table 1.6 shows the mean score difference in level of study on teachers motivation and students academic performance based on Parent Occupation (Government/Private). The calculate $t$ value is statistically a significance at 0.05 levels and hence the hypotheses 4 is accepted. It can be concluded that there is a significant difference in mean score difference in level of study on teachers motivation and students academic performance based on Parent occupation (Government/Private).

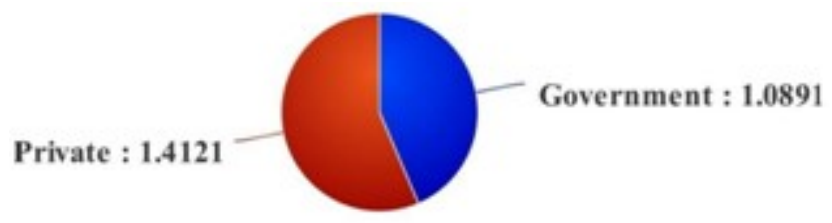

Figure4.3:Relationship Between Students parent occupation and level of Study on Teachers Motivation and Students Academic Performance

\section{SUMMARY}

A study on teachers motivation and students academic performance was studied and the findings reveal that there is a significant difference between level of study on teachers motivation and students academic performance with respect to Teacher standard, School Type and Parent Occupation.

A study on teachers motivation and students academic performance was studied and the findings reveal that there is no significant difference between level of study on teachers motivation and students academic performance with respect to parents education.

\section{LIMITATIONS}

- The study has certain limitation, which are as follows:

Only 282 students are selected as sampling for the study.

The project has been restricted to analyze and study in teacher motivation and its impact on academic achievement among students .

The study is restricted to the school students of Coimbatore.

\section{CONCLUSION \\ RECOMMENDATIONS \\ AND}

FUTURE

$>$ A Similar Study can be conducted for dissertation by taking more number of concepts and students.

> The study can be conducted to other schools around Tamilnadu.

$>$ Present survey helps to investigate the impact level of higher secondary commerce students.

$>$ A similar study can also be conducted using various variables. 
The conclusion is that there is a significant relationship between Teacher standard, School Type and Parent Occupation on impact of teacher motivation among students. While taking decision on impact of teacher motivation among students their Parent Occupation and School Type has to be taken for decision making process.

\section{BIBLIOGRAPHY}

1. Abdullah, A. G. K., Ling, Y. L., \&Sufi, S. B. (2018). Principal Transformational Leadership and Teachers

2. Ahluwalia, A. K., \& Preet, K. (2018). Work Motivation, Organizational Commitment and Locus of Control vis-a-vis Work Experience amongst University Teachers. SAMVAD, 14, 2633.

3. Anderman, L. H., Andrzejewski, C. E., \&Allen, J. (2011). How Do Teachers Support Students Motivation and Learning in Their Classrooms?. Teachers College Record, 113(5), 969-1003.

4. Barbieri, G., Rossetti, C., \&Sestito, P. (2017). Teacher motivation and student learning. Politica economica, 33(1), 59-72.

5. Batra, P. (2014). Problematising teacher education practice in India: Developing a research agenda. Education as Change, 18(sup1), S5-S18.

6. Butler, R. (2012). Striving to connect: Ex- tending an achievement goal approach to teacher motivation to include relational goals for teaching. Journal of Educational Psychology, 104(3), 726.

7. Goel, D. R., \&Goel, C. (2016). Teacher education scenario in India: Current problems \&concerns. MIER Journal of Educational Studies, Trends and Practices, 2(2).

8. Han, J., \&Yin, H. (2016). Teacher motivation: Definition, research development and implications for teachers. Cogent Education, 3(1), 1217819.

9. Jagan, P., Fareed, N., Battur, H., Khanagar, S., \& Bhat, M. (2018). Conceptual knowledge of oral health among school teachers in South India, India. European journal of dentistry, 12(1), 43.

10. Minckler, C. H. (2014). School leadership that builds teacher social capital. Educational Management Administration \&Leadership, 42(5), 657-679.
11. Mishra, S., \&Singh, A. (2017). Higher education faculty attitude, motivation and perception of quality and barriers towards OER in India. Motivation. Asian Education Studies, 3(1), 36.

12. Schiefele, U. (2017). Classroom management and mastery oriented instruction as mediators of the effects of teacher motivation on student motivation. Teaching and Teacher Education, 64, 115-126.

13. Sehgal, P., Nambudiri, R., \&Mishra, S. K. (2017). Teacher effectiveness through motivate- efficacy, collaboration and principal leadership. International Journal of Educational Management, 31(4), 505-517.

14. Singh, R., \&Sarkar, S. (2015). Does teaching quality matter? Students learning outcome related to teaching quality in public and private primary schools in India. International Journal of Educational Development, 41, 153-163.

15. Wang, M. T., \&Eccles, J. S. (2013). and academic engagement: School context, achieve- ment motivation, A longitudinal study of school engagement using a multidimensional perspective. Learning and Instruction, 28, 12-23.

16. Yuan, K., Le, V. N., McCaffrey, D. F., Marsh, J. A., Hamilton, L. S., Stecher, B. M., \&Springer,

17. M. G. (2013). Incentive pay programs do not affect teacher motivation or reported practices: Results from three randomized studies. Educational Evaluation and Policy Analysis, 35(1), 3-22.

18. Yuan, R., \&Zhang, L. J. (2017). Exploring student teachers motivation change in initial teacher education: A Chinese perspective. Teaching and Teacher Education, 61, 142-152

\section{APPENDICES}

\section{PERFORMA FOR BASIC DATA}

1. Name of the student :

2. Name of the School :

3. Teacher Standard : B.Ed [ ] M.Ed [ ]

4. School Type : Government[ ] Private [ ]

5. Parent Education : Educated [ ] Private [ ]

6. Parent Occupation : Government [ ] Private [ ] 


\section{QUESTIONNAIRE}

\begin{tabular}{|c|c|c|c|}
\hline S. & Question & \multicolumn{2}{|c|}{ Answer } \\
\hline 1 & In your view, has motivation ever used for academic achieveent? & Yes & No \\
\hline 2 & Has motivation ever used for the learning of any of your family or friends? & Yes & No \\
\hline 3 & Apart from motivation, are you aware different motivate development activities? & Yes & No \\
\hline 4 & Do you feel the way of learning is generally changing in recent years? & Yes & No \\
\hline 5 & Have you heard of" Everyone is Unique"? & Yes & No \\
\hline 6 & $\begin{array}{l}\text { Do you think individual skills are something that is helping or is going to improve, } \\
\text { Personally? }\end{array}$ & Yes & No \\
\hline 7 & Do you think anything can be done to improve motivate development skills? & Yes & No \\
\hline 8 & Have your ever taken, or do you regularly take, any steps for motivate improvement? & Yes & No \\
\hline 9 & Are trainees already aware of motivation? & Yes & No \\
\hline 10 & Is there anything motivate development help us in Knowledge gaining? & Yes & No \\
\hline 11 & Will learn through motivate development be affect our personality? & Yes & No \\
\hline 12 & Would a motivate development really change the academic achievement level of students? & Yes & No \\
\hline 13 & Are motivation taught more than books? & Yes & No \\
\hline 14 & Can motivation really essentials for students in future? & Yes & No \\
\hline 15 & Can motivation lead to better teaching? & Yes & No \\
\hline 16 & Will motivation actually bring obstruction to some trainees? & Yes & No \\
\hline 17 & Could motivation ever" Complex process"? & Yes & No \\
\hline 18 & Have the Knowledge from motivation useful in exams? & Yes & No \\
\hline 19 & Is there formal way of motivation is under way? & Yes & No \\
\hline 20 & Are you concerned about motivate development? Scientific & Yes & No \\
\hline 21 & Are you aware of the impacts of motivate development? & Yes & No \\
\hline 22 & Are you aware of the causes and effects of motivate development? & Yes & No \\
\hline 23 & Do trainees also share their learning with others through motivate development? & Yes & No \\
\hline 24 & Couldn't the usage of technology cause the motivate development? & Yes & No \\
\hline 25 & Don't trainees learn more ideas from motivate development than textbooks? & Yes & No \\
\hline 26 & Hasn't education system improved or demoted after motivate development adaptation? & Yes & No \\
\hline 27 & Are there positive benefits from motivate development? & Yes & No \\
\hline 28 & Can we pay additional fee for motivation? & Yes & No \\
\hline 29 & Are practical approaches are missed in motivation? & Yes & No \\
\hline 30 & Will motivation cause the limited learning opportunities? & Yes & No \\
\hline
\end{tabular}

